\title{
Penyuluhan Tentang Manfaat Jus Tomat Untuk Menurunkan Tekanan Darah pada Klien Hipertensi di Desa Talang Lebar Tanggamus Lampung
}

\author{
Djunizar Djamaludin ${ }^{1}$, Devi Surya Qaulia ${ }^{\left.2^{*}\right)}$, Dewi Kusumaningsih ${ }^{3}$ \\ Program Studi Ilmu Keperawatan Universitas Malahayati
}

\author{
Corresponding Author: \\ Devi Surya Qaulia. \\ Mahasiswa Program Profesi Ners Universitas Malahayati \\ Email: devinata.1995@gmail.com
}

\begin{abstract}
Abstrak. Dari 10 besar penyakit terbanyak di Provinsi Lampung, pada tahun 2013 hipertensi menduduki urutan ketujuh dengan jumlah 17,29\% dan meningkat menjadi urutan kelima pada tahun 2014 dengan jumlah 30,01\% dan pada tahun 2015 hipertensi meningkat lagi menjadi urutan ketiga dengan jumlah 33,05\%. Berdasarkan penelitian diketahui bahwa diet yang menitik beratkan pada makanan rendah lemak, tinggi sayur dan buah-buahan mampu menurunkan tekanan darah pada penderita hipertensi contohnya tomat. Setelah dilaksanakannya penyuluhan dan demonstrasi, diharapkan pemberian jus tomat dapat untuk menurunkan tekanan darah pada klien hipertensi. Adapun kegiatan yang dilakukan berupa penyuluhan menggunakan leaflet dan demonstrasi pembuatan jus tomat. Terdapat penurunan tekanan darah pada klien hipertensi setelah pemberian jus tomat selama 7 hari di Desa Talang Lebar, Tanggamus. Dengan demikian, pemberian jus tomat pada klien hipertensi sangat efektif dalam menurunkan tekanan darah.
\end{abstract}

Kata kunci: Jus tomat, tekanan darah, hipertensi

Abstract: Of the 10 biggest diseases in Lampung Province, in 2013 hypertension was seventh (17.29\%) and increased to fifth in $2014(30.01 \%)$ and in 2015 hypertension increased again to third (33, 05\%). Based on research it is known that a diet that focuses on low-fat foods, high in vegetables and fruits can reduce blood pressure in people with hypertension such as tomatoes. The aim after counseling and demonstration, is expected to provide tomato juice to reduce blood pressure in hypertensive clients. The activities carried out in the form of counseling using leaflets and demonstrations of making tomato juice. There was a decrease in blood pressure in hypertensive clients after giving tomato juice for 7 days atTalang Lebar Village, Tanggamus. Thus, giving tomato juice to hypertensive clients is very effective in lowering blood pressure.

Keywords: Tomato juice, blood pressure, hypertension

\section{Pendahuluan}

Hipertensi masih menjadi masalah kesehatan pada kelompok lansia, dengan bertambahnya umur, maka tekanan darah juga akan meningkat karena adanya penumpukan zat kolagen pada lapisan otot, sehingga pembuluh darah akan berangsur-angsur menyempit dan menjadi kaku. Setelah umur 45 
tahun, dinding arteri akan mengalami penebalan. Secara umum, dengan bertambahnya usia maka tekanan darah akan bertambah tinggi, baik tekanan darah sistolik maupun tekanan darah diastolik. Hipertensi sebagai salah satu penyakit degeneratif yang sering dijumpai pada kelompok lansia (Tedjasukmana, 2012).

Hipertensi atau yang lebih dikenal dengan penyakit darah tinggi adalah peningkatan abnormal tekanan darah, baik tekanan darah sistolik maupun tekanan darah diastolik. Hipertensi, yang merupakan salah satu faktor risiko kunci penyakit kardiovaskuler, masih menjadi masalah kesehatan masyarakat yang sangat serius di seluruh dunia. Data World Health Organization (WHO) tahun 2015 menunjukkan sekitar 1,13 Miliar orang di dunia menyandang hipertensi, artinya 1 dari 3 orang di dunia terdiagnosis hipertensi. Jumlah penyandang hipertensi terus meningkat setiap tahunnya, diperkirakan pada tahun 2025 akan ada 1,5 Miliar orang yang terkena hipertensi, dan diperkirakan setiap tahunnya 10,44 juta orang meninggal akibat hipertensi dan komplikasinya (Kemenkes RI, 2019).

Hasil Riset Kesehatan Dasar (Riskesdas) 2018 secara nasional terjadi peningkatan prevalensihipertensi berdasarkan wawancara (apakah pernah didiagnosis nakes dan minum obathipertensi) dari 7,6 persen pada tahun 2013 menjadi 9,5 persen pada tahun 2018. Berdasarkan Profil Kesehatan Provinsi Lampung tahun 2017, penyakit terbanyak pada lanjut usia adalah hipertensi $(57,6 \%)$, artritis $(51,9 \%)$, stroke $(46,1 \%)$, masalah gigi dan mulut $(19,1 \%)$, penyakit paru obstruktif menahun $(8,6 \%)$ dan diabetes mellitus $(4,8 \%)$.

Sedangkan di Provinsi Lampung kasus hipertensi menempati urutan pertama terbanyak yaitu 30\% (Dinkes Provinsi Lampung, 2016). Berdasarkan profil kesehatan Kabupaten Tanggamus diketahui bahwa jumlah penderita hipertensi 1.537 atau $70.99 \%$ dari seluruh penduduk usia $>15$ tahun yang melakukan pemeriksaan tekanan darah dan merupakan yang tertinggi di Puskesmas Kota Agung kasus hipertensi menempati urutan ke tiga dari 10 penyakit besar yang ada dengan jumlah kasus 359 kasus.

Meningkatnya prevalensi hipertensi dihubungkan dengan pertumbuhan populasi, penuaan dan faktor risiko perilaku seperti diet yang tidak sehat, konsumsi alkohol, kurangnya aktivitas fisik, berat badan berlebih, serta paparan terhadap stres yang menetap. Dampak hipertensi yang merugikan bagi kesehatan semakin bertambah disebabkan banyak orang dengan hipertensi ternyata juga memiliki faktor risiko kesehatan lain yang menambah risiko serangan jantung, stroke, dan gagal ginjal. Faktorfaktor risiko ini termasuk perilaku merokok, obesitas, kolesterol tinggi, dan diabetes melitus (WHO, 2013).

Penanganan secara farmakologis terdiri atas pemberian obat yang bersifat diuretik, beta blocker, calcium chanell blocker, dan vasodilator dengan memperhatikan tempat, mekanisme kerja dan tingkat kepatuhan. Penanganan secara farmakologis ini mempunyai efek samping yang bermacam-macam tergantung dari lama serta durasi obat yang digunakan. Contohnya penggunaan obat yang dalam durasi lama bisa merusak fungsi ginjal (Smeltzer \& Bare, 2010).

Pengobatan non farmakologis adalah pengobatan yang berasal dari bahan-bahan alami biasanya bahan-bahan ini mudah untuk didapatkan dan biayanya relatif murah. Pengobatan non farmakologis bersifat terapi pengobatan alamiah diantaranya adalah dengan terapi herbal, terapi nutrisi, relaksasi progresif, meditasi, terapi tawa, akupuntur, akupresur, aromaterapi, refleksiologi dan hidroterapi yang meliputi rendam kaki air hangat (Sudoyo, 2006).

Alasan memilih jus tomat dikarenakan selain tindakan ini praktis, mudah, murah bisa dijangkau dan bisa diterapkan bagi pasien hipertensi serta tidak mempunyai efek samping. Untuk tindakan farmakologis sendiri obat adalah sesuatu zat kimiawi yang meskipun tujuannya untuk mengobati tetapi apabila dikonsumsi dalam jangka panjang akan memberikan efek yang merugikan bagi tubuh (Hambing, 2006). 
Alasan saya memilih tempat penyuluhan kesehatan tentang Hipertensi dan demontrasi tentang pemberian jus tomat di Desa Talang Lebar, Tanggamus ialah karena keluarga saya sendiri memiliki masalah kesehatan hipertensi. dimana tujuan umum dalam kegiatan diharapkan pemberian jus tomat dapat menurunkan tekanan darah pada klien hipertensi. Dan tujuan khusus dalam kegiatan yaitu asuhan keperawatan, telaah jurnal untuk menentukan intervensi, evaluasi hasil aplikasi intervensi, perbandingan hasil intervensi pemberian jus tomat.

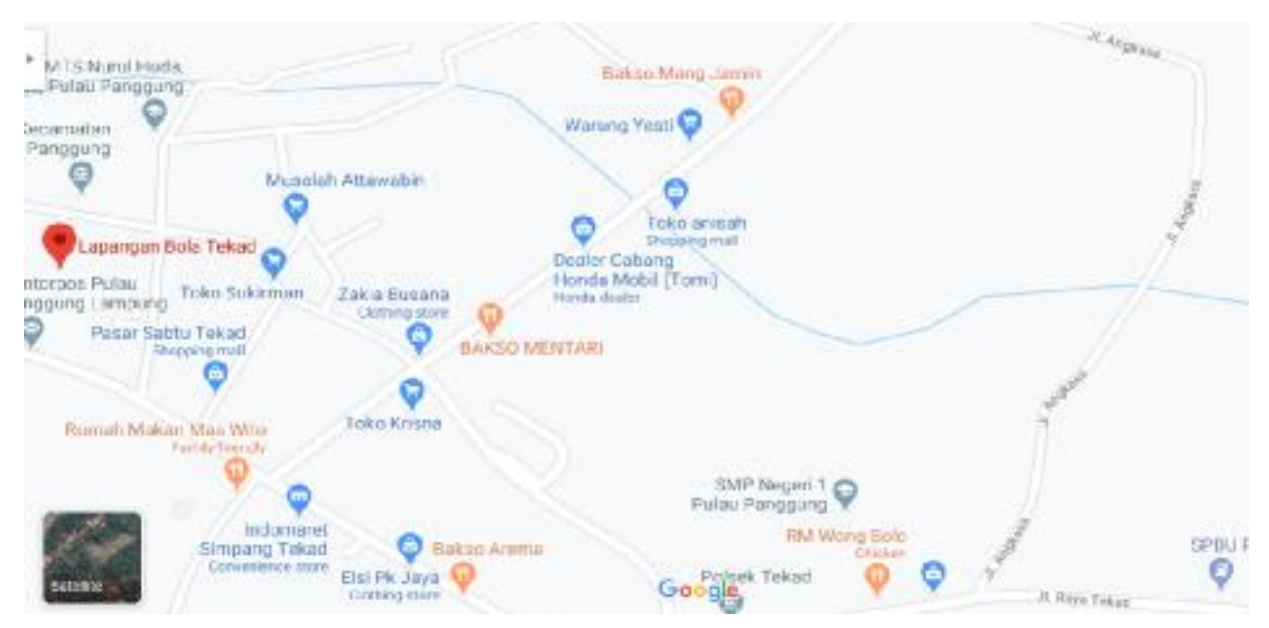

Gambar 1. Gambar: Lokasi penyuluhan dan demonstrasi

\begin{abstract}
Metode
Tahap persiapan dari kegiatan adalah pembuatan pre planning, persiapan penyajian leaflet dan demostrasi, tempat dan alat-alat lainnya disiapkan oleh peneliti. Pembuatan leaflet dibuat pada hari kamis 11 Mei 2020, pada tanggal 12 Mei 2020 dilakukan penyuluhan, pengecekan tekanan darah, dan demostrasi pembuatan jus tomat. Kegiatan ini dengan pemberitahuan kepada klien. Dan dilanjutkan penyuluhan penyuluhan, pengecekan tekanan darah, dan demostrasi pembuatan jus tomat.

Peserta hadir 1 orang yaitu perempuan. Setting tempat sudah sesuai dengan rencana dan perlengkapan yang dilakukan untuk penyuluhan sudah tersedia dan sudah digunakan sebagaimana mestinya. Peran peneliti sebagai modertor, notulen, observer, dan juga fasilitator. Penggunaan bahasa yang dipraktekkan sudah komunikatif dalam penyampaianya, klien dapat memahami dan dapat mempraktekkan kembali yang di demonstrasikan. Pelaksanaan kegiatan dilaksanakan pukul $09.00 \mathrm{~s} / \mathrm{d}$ 09.30 WIB. Sesuai dengan jadwal yang sudah ditentukan. Klien dapat memahami dan mengerti tentang pengertian terapi pemberian jus tomat. Klien dapat memahami dan mengerti tentang tujuan dilakukannya terapi pemberian jus tomat. Klien dapat memahami dan mengerti tentang manfaat dan teknik pembuatan terapi pemberian jus tomat. Klien dapat memahami dan mengerti tentang langkahlangkah pembuatan jus tomat
\end{abstract}

\title{
Hasil dan Pembahasan
}

Pelaksanaan pemberian terapi pembuatan jus tomat dilaksanakan pada tanggal 12 Mei $2020 \mathrm{~s} / \mathrm{d}$ 18 Mei 2020. Penelitian dilakukan selama 7 hari, setelah dilakukan nya pemberian terapi selama 7 hari 
menurunkan tekanan darah klien. Berikut gambar pelaksanaan penyuluhan, pengecekan tekanan darah dan pemberian terapi jus tomat:
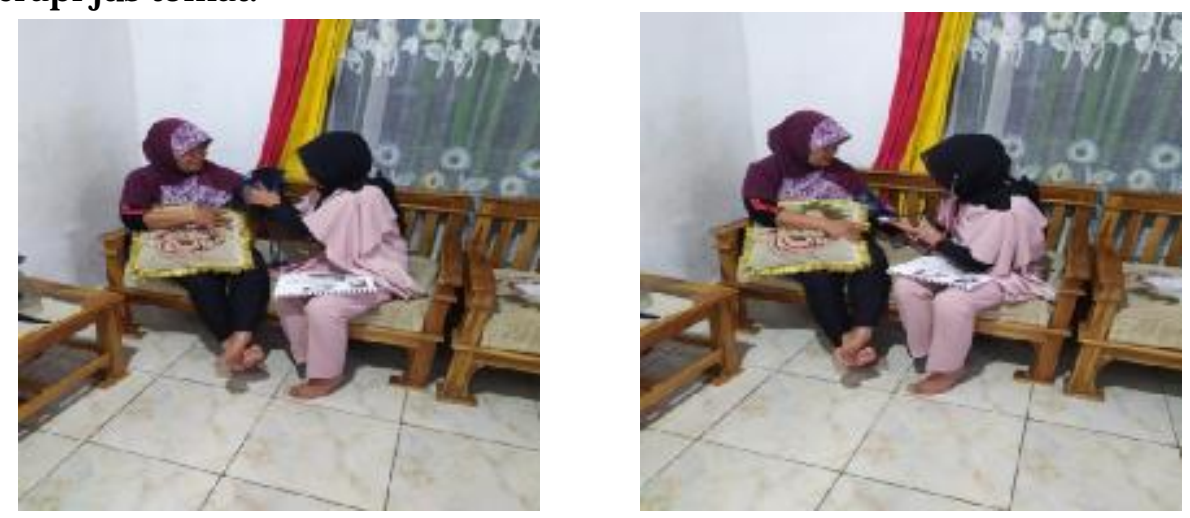

Gambar 4.1 pelaksanaan penyuluhan jus tomat dan pengecekan tekanan darah

Setelah mengkonsumsi jus tomat selama 7 hari pada Ny.W mengalami penurunan tekanan darah yaitu TD $130 / 90 \mathrm{mmHg}$.

\begin{tabular}{cccccccc}
\hline \multicolumn{9}{c}{ Tekanan Darah } \\
\hline Hari ke 1 & Hari ke 2 & Hari ke 3 & Hari ke 4 & Hari ke 5 & Hari ke 6 & Hari ke 7 \\
\hline $150 / 100$ & $140 / 100$ & $150 / 90$ & $140 / 90$ & $140 / 90$ & $130 / 90$ & $130 / 90$ \\
\hline
\end{tabular}

Menurut Suma'mur (2009), ritmesirkadian manusia sedikit atau banyakterganggu oleh sistem kerja malam-tidur siang. Fungsi-fungsi fisiologis tenaga kerjatidak dapat disesuaikan sepenuhnya denganirama kerja demikian. Hal ini mudahdibuktikan dari pengukuran suhu badan,nadi, tekanan darah, dan lain-lain dari orang yang bekerja malam dibandingkan dengankeadaan waktu bekerja siang hari.

Hasil penelitian ini sejalan dengan penelitian Rahayu (2017) tentang efektifitas minum jus tomat terhadap tekanan darah padawanita menopause dengan hipertensi di Posyandu Kantil Kelurahan Pojok Kota Kediri Tahun 2015, setelah minum jus tomat dari 11 responden mengalami perubahan tekanan darah. Nilaimean systole menjadi 133,181 mmHg. Sedangkan, nilai mean diastole 87,27 $\mathrm{mmHg}$. Hasil uji Wilcoxon diperoleh $P$ value = 0,002 sistole dan 0,034 untuk diastole, maka nilai $P$ value $>a$, halini berarti H0 diterima dan H1 ditolak. Jadi kesimpulannya ada perbedaan tekanan darah sebelum dan setelah dilakukan pemberian jus tomat pada pasien hipertensi di Posyandu Kantil Kelurahan Pojok Kota Kediri Tahun 2015.

Selain itu berdasarkan penelitian Suwanti (2018) tentang pengaruh pemberian jus tomat terhadap tekanan darah lansiapenderita hipertensi di Desa Lemahireng Kecamatan Bawen menunjukkan ratarata tekanan darah sistole lansia sebesar164,47 $\mathrm{mmhg}$, sesudah diberikan jus tomat turun menjadi 150,53 mmhg. Sedangkan tekanan darah diastolenya juga mengalami penurunan dari 93,00 mmhg sebelum diberikan jus tomat menjadi 85,53 setelah diberikan jus tomat.

Selain itu faktor yang berpengaruh terhadap perbedaan penurunan tekanan darah adalah kebiasaan konsumsi natrium pada klien dimana Ny.W masih mengkonsumsi garam seperti biasa atau tidak mengurangi asupan natrium pada masakannya. 


\section{Kesimpulan}

Terapi non farmakologi pemberian jus tomat terbukti dapat menurunkan tekanan darah pada penderita hipertensi. Hal ini membuktikan beberapa hasil penelitian yang pernah dilakukan kepada klien dengan hipertensi, bahwa pemberian jus tomat dapat dijadikan alternatif perawatan hipertensi yang murah, mudah, dan aman.

\section{Daftar Pustaka}

Balitbang Kemenkes RI. 2013. Riset Kesehatan Dasar; RISKESDAS. Jakarta: Balitbang Kemenkes RI

Bogdanov, S., Jurendic, T., Sieber, R., Gallmann, P. (2008) Honey for Nutrition and health: A Review. J. Am. Coll. Nutr., 27, p677-689

Dinkes Provinsi Lampung, 2016. Profil Kesehatan Provinsi Lampung.

Efendi. (2009). Keperawatan Kesehatan Komunitas: Teori Dan. Praktek Dalam Keperawatan. Jilid 1. Jakarta : Salemba Medika

ESH/ESC.(2013). ESH/ESC Guidelines for the management of arterial hypertension. Journal of Hypertention.Volume 31 Number 7 July 2013

Fandana, R. (2020). Diabetes Mellitus Pada Petani. Wellness And Healthy Magazine, 2(1), 1 - 4 . Retrieved from https://wellness.journalpress.id/wellness/article/view /21001

Fatimah. 2010. Merawat Manusia Lanjut Usia. Jakarta : Trans Info Media

Hidayat. (2009). Asuhan keperawatan hipertensi. Diakses pada tanggal 25 Februari2018, dari http:/hidayat2.com/2009/05/12/askep-hipertensi

Hikayati., Flora, R. Purwanto, S. 2014. Penatalaksanaan Non Farmakologis Terapi Komplementer Sebagai Upaya untukMengatasi dan Mencegah Komplikasi pada PenderitaHipertensi Primer di Kelurahan Indralaya Mulya KabupatenOgan Ilir. Universitas Sriwijaya

Hurlock, E.B. (2002). Psikologi Perkembangan: Suatu Pendekatan Sepanjang Rentang Kehidupan (edisi kelima). Jakarta : Erlangga

JNC VII. (2003). The seventh report of the Joint National Committee on prevention, detection, evaluation, and treatment of high blood pressure. Hypertension, 42:1206-52. http:/hyper.ahajournals.org/cgi/content/full

Mansjoer, Arif, dkk. (2012). Kapita selekta kedokteran. Jakarta: Media Aesculapius FKUI.

Maryam, Siti., Ekasari., Mia Fatma., Rosidawati.( 2012). Mengenal Usia Lanjut dan Perawatannya. Jakarta: Salemba Medika

Masriadi. (2016). Epidemiologi Penyakit Tidak Menular. Jakarta: Trans Info. Media.

Mukhlis, H., \& Marini, M. (2020). Pengaruh terapi murottal terhadap denyut nadi dan pernafasan pada bayi dengan berat badan lahir rendah. Indonesia Berdaya, 1(1), 29 - 37. Retrieved from https://www.ukinstitute.org/gournals/ib/article/view/v1i105

Mukti, B., Mukhlis, H., Amirudin, I., \& Sutrisno, S. (2019). Prokrastinasi Akademik Ditinjau dari Konsep 
Diri Mahasiswa Profesi Ners. Journal of Psychological Perspective, 1(2), 15-22. Retrieved from https://www.ukinstitute.org hournals/jopp/article/view hoppv1i102

Noni, S, (2007). Sehat dan Cantik Berkat Teh Hijau. Jakarta: Penebar Plus.

Nugraheni, S.D. (2005). Hubungan antara Kecerdasan Ruhaniah dengan Kecemasan Menghadapi Kematian pada Lanjut usia. Jurnal Ilmiah Psikologi INSIGHT Th. II/No. 2/2004, 80-89.

Papalia, D.E, dkk. (2009). Human Development : Perkembangan Manusia (Buku 2 edisi 10). Jakarta : Salemba Humanika

Rahajeng, E. \&Tuminah, S., 2009. Prevalensi Hipertensi dan Determinannya di. Indonesia. Majalah Kedokteran Indonesia. 59(12): 580-587

Sitorus, Rico Januar (2008) Faktor-Faktor Risiko Yang Mempengaruhi Kejadian Stroke Pada Usia Muda Kurang Dari 40 Tahun (Studi Kasus Di Rumah Sakit Di Kota Semarang). Jurnal Epidemiologi . (Unpublished)

Stanley, M \&Beare, PG. (2007). Buku Ajar Keperawatan Gerontik. Jakarta : EGC.

Tedjasukmana P. 2012. Tata Laksana Hipertensi. Departemen Kardiologi, RS Premier Jatinegara dan RS Grha Kedoya. Jakarta: Indonesia.

Triyanto, Endang. 2014. Pelayanan Keperawatan bagi Penderita Hipertensi secara Terpadu. Yogyakarta: Graha Ilmu.

Wahyudi, D., \& Arlita, I. (2019). Progressive Muscle Relaxation Terhadap Kadar Glukosa Darah Diabetes Melitus Tipe 2 Terkontrol dan Tidak Terkontrol. Wellness And Healthy Magazine, 1(1), 93 100. Retrieved from https:/wellness.journalpress.id/wellness/article/view/w1112

World Health Organization. (2013). Hypertension Fact Sheet. WHO: Department of Sustainable Development and Healthy Environments.

Yogiantoro, M., 2009. Hipertensi Esensial. In: Sudoyo, A.W., et al eds. Buku Ajar Ilmu Penyakit Dalam 5th ed. Jilid II. Jakarta: Interna Publishing, 1079-1085. 